\title{
Prospects for Sugar Palm (Arenga pinnata) Development for Food and Energy Security
}

\author{
Fitra Syawal Harahap ${ }^{* 1)}$,Hilwa Walida'), Rosmidah Hasibuan ${ }^{2)}$, Abdul \\ Rauf $^{3)}$,T. Sabrina ${ }^{3)}$, Benny Hidayat ${ }^{3)}$, Rahmawaty ${ }^{4}$, Darmadi Erwin \\ Harahap $^{5)}$, Parmanoan Harahap ${ }^{6}$
}

\begin{abstract}
${ }^{I}$ Study program Agrotechnology, Faculty of Science and Technology, Universitas Labuhanbatu
${ }^{2}$ Study Program Education Biology, Faculty of Teacher Training and Education, Universitas Labuhanbatu

${ }^{3}$ Study Program Agrotechnology, Faculty of Agriculture, Universitas Sumatera Utara

${ }^{4}$ Study Program Forest, Management Faculty of Forestry, Universitas Sumatera Utara

${ }^{5}$ Study Program Agrotechnology, Faculty of Agriculture, Universitas Muhammadiyah Tapanuli Selatan

${ }^{6}$ Study Program Agrotechnology, Faculty of Agriculture, Universitas Graha Nusantara Padang

Sidempuan
\end{abstract}

\begin{abstract}
The use of sugar palm can be felt directly by the community both in and around the forest through traditional use. But unfortunately this plant does not get enough attention to be developed, so that the palm trees that are used in general are still plants that grow wild in nature and develop naturally. The purpose of this activity is to provide information on how the development of sugar palm can be an alternative food security and energy and processed products from coconut trees, so that it benefits the community, encourages public awareness and awareness to preserve the environment. This activity was carried out in Buluh Awar Village by involving the community and Teaching Staff of the Agrotechnology Study Program, Faculty of Science, Labuhan Batu Universitas. the material used and the method used are planting sugar palm which is generally not yet cultivated so that crop productivity is low and it is feared the plant population will decline. Because sugar palm plants have economic, social, cultural and conservation functions, so as to cultivate palm trees and rehabilitate plants that grow naturally and irregularly to increase crop productivity. The results of the dedication show that planting sugar palm plants have good hopes or prospects in the future, namely processed products from palm oil plants such as sugar, drinks and vinegar can be used to increase food security, while bioethanol can be used as an alternative energy source.
\end{abstract}

Keywords: Sugar palm, Food security, Alternative energy

Abstrak. Kegunaan aren dapat dirasakan secara langsung oleh masyarakat baik di dalam maupun di sekitar hutan melalui penggunaan secara tradisional. Namun

\footnotetext{
*Corresponding author at: Agrotechnology, Faculty of Science and Technology, Universitas Labuhanbatu

E-mail address: fitrasyawalharahap@gmail.com
} 
sayang tumbuhan ini kurang mendapat perhatian untuk dikembangkan, sehingga pohon aren yang dimanfaatkan pada umumnya masih merupakan tumbuhan yang tumbuh liar di alam dan berkembang secara alami. Tujuan dari kegiatan ini adalah untuk memberikan informasi tentang bagaimana Pengembangan Tanaman Aren dapat menjadi alternatif ketahanan pangan dan energi serta produk olahan dari pohon aren, sehingga bermanfaat bagi masyarakat, mendorong kesadaran dan kesadaran masyarakat untuk melestarikan lingkungan. Kegiatan ini dilakukan di Desa Buluh Awar dengan melibatkan masyarakat dan Staf Pengajar Program Studi Agroteknologi, Fakultas Sains, Universitas Labuhan Batu. Bahan yang digunakan serta metode yang digunakan adalah penanaman aren yang umumnya belum dibudidayakan sehingga produktivitas tanaman rendah dan dikhawatirkan populasi tanaman akan menurun. Karena tanaman aren memiliki fungsi ekonomi, sosial, budaya dan konservasi, sehingga untuk membudidayakan tanaman aren dan merehabilitasi tanaman yang tumbuh secara alami dan tidak teratur untuk meningkatkan produktivitas tanaman. Hasil dari pengabdian menunjukkan bahwa penanaman tanaman aren memiliki harapan atau prospek yang baik di masa depan yaitu Produk olahan dari tanaman kelapa sawit seperti gula, minuman, dan cuka dapat digunakan untuk meningkatkan ketahanan pangan, sedangkan bioetanol dapat digunakan sebagai sumber energi alternatif.

Kata Kunci: Tanaman aren, Ketahanan pangan, Energi alternatif

Received 14 September 2019 | Revised 15 October 2019 | Accepted 15 November 2019

\section{Introduction}

The palm tree is a tree that almost all parts both physical and production can be utilized and have valued the economy. Palm production such as fruit, roomie and flour for a long time has been used traditionally by the community and not yet can produce significant economic value [1]. This time sugar products, palm sugar, palm sugar and fro have entered the modern but deep market very limited quantity. Utilization of palm sugar palm juice for Fermented products like vinegar, ethanol, and data are still needed further research and development in technology processing and marketing [2].Sugar palm or areca palm (Arenga pinnata) is widely known and cultivated by farmers in Indonesia. The use of sugar palm mainly as a source of carbohydrates, roomie for making sugar, alcohol, and other benefits [3]. According to [4] sugar palm are ideally used in alley cropping especially on land that has a high degree of slope. At present with technological advances, palm sugar has the potential to be made bioful [5]. The processing and management of palm sugar products carried out by sugar palm farmers / craftsmen in East Kalimantan are still limited to traditional processing of palm sugar into printed sugar whereas processing of palm sugar into ant sugar and bioethanol is 
limited to trials [6]. According to [7]. To ensure the continuity and intensification of the exploitation of sugar palm, it is time to start paying attention to the cultivation of cultivation including cultivation techniques and rehabilitation of sugar palm plants.

The wide distribution of the population and the high diversity of sugar palm makes it difficult to estimate the high or low production of sap which is used as a basis for making palm sugar. This is evident from the results of research conducted, namely, Exploration and Identification of Sugar palm in South Tapanuli Regency with the result that the character of the leaves is the character that has the most significant effect on the production of palm sugar juice [8]. According to [9], there is a sugar palm farmer's behavior which is counter-productive to the production of roomie, among other things, the farmer seems to have no burden to cut the leaves for reasons of ease to tap or to facilitate climbing so as not to be blocked.

With the touch of technology, it is expected that spatial planning will occur between the sugar palm and the cultivation techniques of sugar palm trees that support increased crop productivity and increase farmers' income. At present the main product of palm sugar plantations is tapping from male flowers that are made into palm sugar as well as soft drinks, vinegar and alcohol $[10,11]$. Besides that the sugar palm plants can produce food products such as the foliage of ripe female fruit and palm sugar for food in the form of cakes, bread and biscuits derived from the processing of the plant's spout [12]. In addition, palm trees can also be developed in agroforestry systems between forestry and agricultural crops [13].

Sugar palm plants have not been cultivated intensively and only grow wild in the forest. Research [14], showed that 4 clusters were formed with a $75 \%$ similarity level or $25 \%$ diversity. The number of productive leaves and the percentage of sap sugar content above the average through the Identification of Phenotypic Characters of Arena pinnata Merr in South Tapanuli Regency. Therefore, the development of this plant is very slow while the logging is going very fast, as a result the population of sugar palm is drastically reduced although there are no data on this [15].

The decline in the sugar palm population will directly result in a decrease in the income of farmers who cultivate the sap as the main results of this crop. According to [16], sugar palm plant is a long lived annual plant, so the height of male and female first spangles can be used as indirect selection criteria to increase the yield of roomie. The development of increasing energy needs and limited fossil energy is a concern to look 
for renewable energy sources such as bioethanol derived from vegetable raw materials. Bioethanol is a cheap alternative raw material when compared to gasoline without subsidies. Currently, besides cassava, sugarcane and the distance of potential raw materials to be used as ethanol are sugar palm [17].

Armed with this information, Community Service activities are carried out to give more insight to the community in the Village of Buluh Awar, in Sibolangit District, Deli Serdang Regency, North Sumatra, is one of the sugar producing centers in North Sumatra. About $80 \%$ of the people there earn a living from palm trees, which are actually not planted but grow on their own in the forest or fields. In Buluh Awar, there are about 10 hectares of aren plantations, but not spread over one stretch. The potential of sugar palm plantations there is actually not optimally worked on, can still be developed better and more broadly with more optimal results as well. The purpose of this activity is to provide information on how the development of sugar palm trees can be an alternative food security and energy and processed products from palm trees, so that it benefits the community, encourages public awareness and awareness to preserve the environment.

\section{Methods}

Community service activities are carried out in Mess Aren Hall, Buluh Awar Village, Sibolangit District, Deli Serdang Regency, North Sumatra, starting from the survey and location determination, visits to permits, and counseling activities. Implementation of Community Service will be carried out as follows, Lecture activities carried out by teaching staff by providing material on Arena Development (Arenga pinnata Merr) for Food Safety and Energy with discussion. After completing the presentation material, given the opportunity to discuss the material provided in the form of questions and answers or responses. The aim of Community Service activities is carried out by the teaching staff of the Agrotechnology Study Program of the Faculty of Science and Technology and the Teacher Training and Education Faculty of Labuhanbatu Universitas, the Faculty of Agriculture and Forestry, Universitas of North Sumatra and Graha Nusantara Universitas (UGN) Padang Sidempuan, Rector of Labuhanbatu Universitas Mr. Ade Parlaungan Nasution, SE., M.Si the Chancellor is to increase awareness of all levels of society about the importance of the Development of the Pinnata Merr Arena for Food Safety and Energy in Buluh Awar Village, Sibolangit Regency, Deli Serdang District so that the benefits of implementing community services can be seen from two sides, namely, the Community will benefit from the importance of 
the Development of the Merr Pinnata Arena for Food and Energy Security in Buluh Awar Village, Sibolangit Regency, Deli Serdang Regency,

Increasing community awareness to protect and preserve the environment, especially efforts to manage the importance of the Pinnata Arena Merr for Food and Energy Security in Buluh Awar Village, Sibolangit Regency, Deli Serdang Regency, Benefits for universities and government and Public awareness of higher education in an effort to improve environmental quality, especially the importance of Arena pinnata Merr. Development of Food and Energy Security in Buluh Awar Village, Sibolangit Regency, Deli Serdang Regency as a reflection of the existence of Higher Education in the midst of the community and Assisting government programs in efforts to manage the development of the Aren Factory so that the demand for products produced from this factory will always increase in line with the development of development.

\section{Results and Discussion}

The implementation of community service activities is carried out by means of training and discussion. The lecture was conducted by giving material and practice on how to develop Arenga pinnata Merr for food security and energy. The implementation of activities offered by the community service team from the Faculty of Agriculture and Forestry and Graha Nusantara Universitas (UGN) Padang Sidempuan is providing material on the importance of Arena pinnata Merr for Food and Energy Security in Buluh Awar Village, Sibolangit District, Deli Serdang District After received this training, it is hoped that the community can manage their mangrove forests and manage their land so that the Palm Oil Development can be utilized optimally.

Aren is a plant with high potential to be developed. The main products of the sugar palm plant as a result of tapping the sap of male flowers can be used as sugar, drinks, vinegar and alcohol. Besides other parts of plants can be made food. Data for 2004 total area of sugar palm trees has reached 60,482 ha spread across 14 provinces. In connection with palm sugar products that can be used as raw material for ethanol, the development of this plant to support the needs of bioenergy needs to be immediately followed up. Opportunities to develop these plants in addition to the availability of existing technology, palm trees are easily adaptable to various types of soil throughout Indonesia including critical land, reeds and for reforestation and forest conservation. While the challenges that need to be overcome to develop these plants include: technological input is still minimal, improved production management, improved 
processing, marketing is still traditional, dissemination is still limited to a small number of farmers, and the difficulty of superior seeds.

Aren trees because they have the ability to adapt to various land conditions, agro-climate, and high tolerance in mixed cropping patterns including woody plants and fast growing because they have many roots and thick canopy are very suitable to be developed also on marginal land which is mostly owned by poor farmers. To overcome the increase in the area and the number of poor land areas in Indonesia at a higher rate, it is necessary to plant types such as sugar palm. These plants provide viable sap production with low input and are very suitable for water and soil conservation purposes. Besides that, sugar palm plants produce biomass on the ground and in soils that are so large that it plays an important role in the $\mathrm{CO}_{2}$ cycle [5]. Sugar palm plants can easily adapt to various types of soil cultivated for agricultural commodities including marginal soils, in addition to this plant serves for soil and water conservation. Most of the sugar palm plantations have not implemented existing technological innovations. So that the dissemination of technology will have an impact not only on

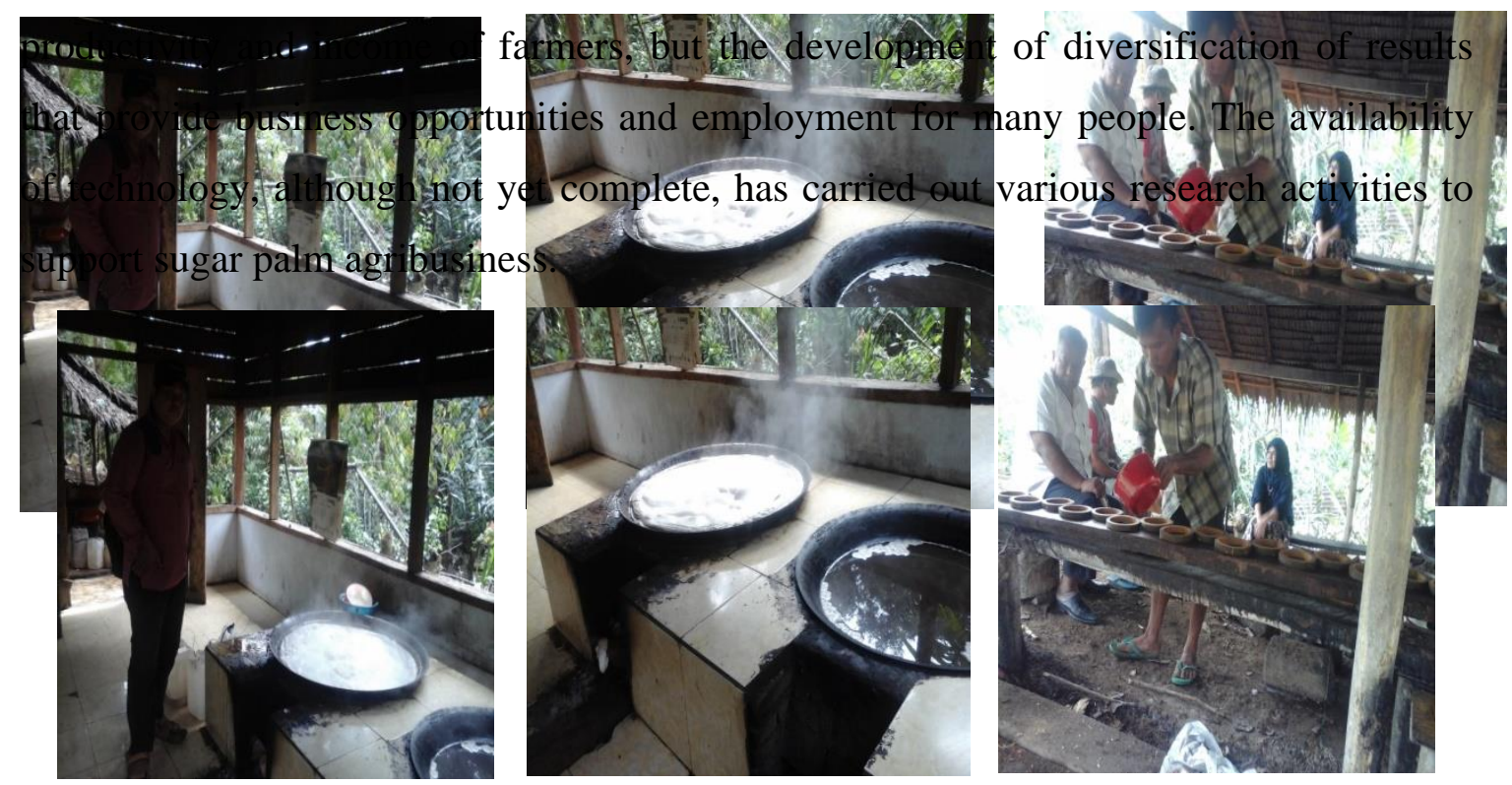

Figure 1. The process of making palm sugar made from palm tree sap

The technology that is ready to use includes: selection of parent plant trees, nurseries, nurseries, cultivation, tapping, sap preservation, sugar processing, ant sugar, sugar palm sugar processing and ethanol production. The process of making palm sugar from palm tree sap can be seen in Figure 1. The available land reserves in each province including critical land, alang grasslands, etc. can be planted with palm trees. The existence of a national movement for forest and land rehabilitation can use palm trees 
for conservation and reforestation programs. Palm trees have the opportunity to become bioethanol-producing plants because of their adaptability to various land and agro-climate conditions. Available technological innovations to develop sugar palm plants as bioethanol producers include: seed sources, cultivation, tapping sap and processing of sap into bioethanol. The potential of sugar palm plants to be used as ethanol is now quite large, reaching 1.43 million bioethanol per year. However, not to become a competitor in food, it is suggested that the development of sugar palm be directed in the form of developing new areas specifically for bioethanol with a pilot orientation of the project in the provinces and districts that are interested. In accordance with national needs, 6.4 million hectares have been planned during 2005-2015 for plants producing bioethanol, including sugar palm. The challenge ahead for the development of sugar palm plants is not only for food sources, but can be used as a source of bioethanol and other product diversification in an effort to increase revenue and land conservation. A pilot project is needed that is integrated with the latest agribusiness-oriented technological innovation applications. Commitments to implementation are left to the provinces/districts to finance, implement and monitor them. Sugar palm research to produce bioethanol by the Agency for Agricultural Research must get top priority. This activity must be designed in the form of short and long term sugar palm research which can clearly produce concrete results in the development of palm trees with environmental conservation areas.

\section{Evaluation}

Implementation in the field was carried out by means of lectures and discussions, by the teaching staff of the Agrotechnology Study Program from the Faculty of Science and Technology of Labuhanbatu Universitas, the Biology Education Study Program of the Faculty of Teaching and Education of Labuhanbatu Universitas, Faculty of Agriculture, Universitas Sumatera Utara at Mess Aren, Buluh Awar (Figure 2). This is done because most people are close to the location. The material presented was very useful for participants because around $90 \%$ of participants who attended lectures and discussions as well as the problems presented could be seen immediately so there was a two-way discussion.

This extension activity also involved local government officials represented by the local village head, Chairperson of the Wampu North Sumatra Watershed Forum, Chairperson of the Deli Serdang District Agricultural Extension Commission, Rector of Labuhanbatu Universitas, Bpk. Ade Parlaungan Nasution, SE, M.Si., Chancellor of the 
Universitas of Nahdlatul Ulama Universitas, North Sumatra. The government officials at the counseling place also welcomed this activity because it was one of the means in increasing the community's insight in their area.
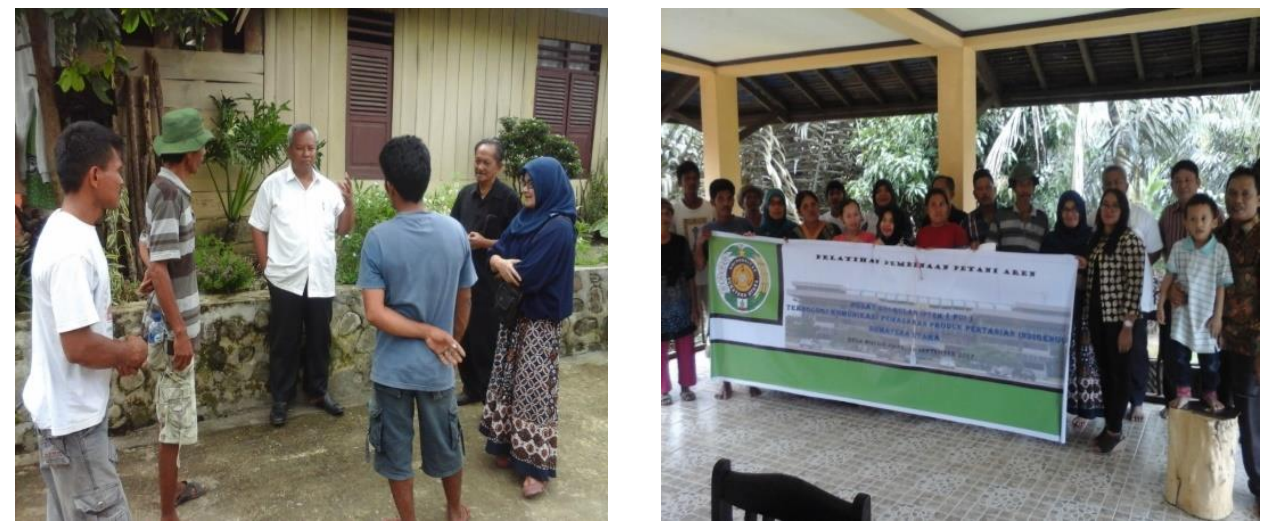

Figure 2. Implementation of community service activities

\section{Supporting factors}

Supporting factors in the implementation of community service that really helped the realization of this activity were positive responses from the community and local government officials. Positive responses were shown with a good reception on the arrival of the counseling team to the location and at the time the lecture was conducted.

\section{Obstacle factor}

As for the inhibiting factors in this service activity, namely: limited space and not all people can participate in this outreach activity, because they already have other activities that coincide with this event. However, this activity was successfully carried out with the participation of a part of the community.

\section{Conclusions}

This Community service is an extension conducted by a lecture and discussion system with participants from the community with material on the Development of (Arenga pinnata) for Food and Energy Security so that the demand for products produced from this plant will always increase in line with developments development. Based on the 
results of the activity, it is necessary to have continuous counseling to the community to understand the importance of the efforts to develop the Sugar plant (Arenga pinnata).

\section{References}

[1] Mariati, R. 2013. Potensi produksi dan prospek pengembangan tanaman aren (Arenga pinnata MERR) di Kalimantan Timur. Agrifor, 12(2): 196-205.

[2] Lempang, M. 2012. Pohon aren dan manfaat produksinya. Info Teknis EBONI, 9(1): 37-54.

[3] Mogea, H. 1991. Revisi marga aren. Disertasi S3 Universitas Indonesia.

[4] Mahmud, Z. Dan Amrizal, 1991. Palma sebagai bahan pangan, pakan dan konservasi. Buletin Balitka No. 14. Balitka Manado.

[5] Sangian, Hanny F., Gerald H. Tamuntuan, Handy I.R. Mosey, Verna Suoth, Beni H. Manialup. 2017. The Utilization of Arenga Pinnata Ethanol In Preparing One Phase-Aqueous Gasohol. ARPN Journal of Engineering and Applied Sciences, 12, no. 24: 7039-7046.

[6] Sangian, H.F. and Tongkukut, S. 2011. Study Of Bio-Ethanol Preparation From Arenga Palm Sugar. Jurnal Ilmiah Sains, 11(2): 259-267.

[7] Bernhard, M.R. 2018. Teknik Budidaya dan Rehabilitasi Tanaman Aren. Buletin Palma, (33): 67-77.

[8] Harahap, M.K. 2018. Karakter Daun dan Produksi Nira Tanaman Aren (Arenga Pinnata Merr) di Kecamatan Marancar. Graha Tani, 4(1): 587-599.

[9] Harahap, P., Rosmayati, R., Harahap, E. M., Harahap, D. E., Harahap, F.S. 2018. Eksplorasi dan Identifikasi Tanaman Aren (Arenga pinnata Merr) di Kabupaten Tapanuli Selatan. Jurnal Pertanian Tropik, 5(3): 423- 427.

[10] Akuba, R.H. 2004. Profil Aren. Pengembangan Tanaman Aren. Prosiding Seminar Nasional Aren. Tondano. Balai Penelitian Tanaman Kelapa dan Palma Lain, 9 Juni. pp. 1-9.

[11]Rindengan, B., Manaroinsong, E. 2009. Aren, Tanaman Perkebunan Penghasil Bahan Bakar Nabati (BBM). Di dalam: Effendi DS, Editor. Prospek Pengembangan Tanaman Aren (Arenga pinnata), pp.15-21.

[12] Maliangkay, R.B., Yulianus Matana, Novalisa Lumentut, E. Manaroinsong. 2004. Budidaya Tanaman Aren. Pengembangan Tanaman Aren. Prosiding Seminar Nasional Aren Tondano, 9 Juni 2004. Balai Penelitian Tanaman Kelapa dan Palma Lain. pp.131-137.

[13] Saleh, M.S., Samuddin, S. Bahry, S. 2007. Karakterisasi Pohon Induk Aren Sebagai Sumber Benih Unggul di Sulawesi Tengah. Laporan penelitian Hibah Bersaing Tahap II.

[14]Effendi, D.S. 2015. Prospek pengembangan tanaman aren (Arenga pinnata Merr) mendukung kebutuhan bioetanol di Indonesia. Perspektif, 9(1): 36-46.

[15] Saleh, M.S., Samudin, S., Bahry, S. 2006. Karakterisasi Morfologi Tanaman Aren di Sulawesi Tengah. J. Agrisains, 7(3): 143-149.

[16] Samudin, S., Saleh, M.S. 2009. Parameter genetik tanaman aren (Arenga pinnata L.). Agroland: Jurnal Ilmu-ilmu Pertanian, 16(1). 
[17]Harahap, P., Harahap, M.K. Harahap, F.S. 2019. Identifikasi Karakter Fenotip Daun Tanaman Aren (Arenga pinnata Merr) di Kabupaten Tapanuli Selatan. Jurnal Pertanian Tropik, 6: 472-476. 